ks. Henryk Dybski

\title{
Teoktysta - matka św. Teodora Studyty
}

\section{THEOKTISTE - THE MOTHER OF ST. THEODORE THE STUDITE}

The aim of the article is to discuss Theoktiste's curriculum vitae. This does not mean, however, that focusing primarily on her person, one can skip all the content relating to her son, St. Theodore. What weighs in favour of it, is the close ties between them that deepened in the course of mutual experiences - both in the family house in Constantinopole and later, when both led religious life. In addition, their lives influenced each other to such an extent, that it would be difficult to understand important decisions taken by Theodore, especially in his youth, without the prior influence of his mother.

Key words: Byzantine studies, hagiography, asceticism, monasticism, cenobitism.

W 57. tomie „Vox Patrum” wydanym z okazji jubileuszu 70-lecia urodzin zasłużonego dla patrologii polskiej ks. prof. Wincentego Myszora, ukazał się mój artyku1 ${ }^{1}$, w którym wymienione zostały cztery starożytne Vitae św. Teodora Studyty (759-826), ich autorzy, czas powstania i wydania krytyczne. Ostatni zaś rozdział (szósty) tej publikacji ${ }^{2}$ poświęcony jest jego biografii. Napisana ona została w oparciu o Vita Sancti Theodori Studitae $A^{3}$, autorstwa Teodora Dafnopaty, historyka,

$1 \quad$ Por. H. Dybski, Wydania krytyczne, czas powstania i autorzy starożytnych , $\dot{Z} y$ wotów” św. Teodora Studyty. Jego „curriculum vitae” w oparciu o „Żywot A”, „Vox Patrum” 32(2012) t. 57, s.137-154.

2 Por. tamże, s. 145-152. W cytowanym wyżej artykule, znajduje się również wyjaśnienie słowa „Studyta”, które występuje przy imieniu św. Teodora: zob. tamże, s. 149-150. 
żyjącego w pierwszej połowie X wieku. W Żywocie tym zawarte są najważniejsze wydarzenia, dotyczące życia i działalności św. Teodora. Vita $A$ nie wyczerpuje jednak tego zagadnienia, lecz je tylko syntetycznie przedstawia w porządku chronologicznym. Natomiast informacje uzupełniające i znacznie poszerzające ten temat, znajdują się $\mathrm{w}$ obszernej spuściźnie literackiej Teodora Studyty ${ }^{4}$. Obecne są one m.in. w jego utworze pochwalnym, napisanym ku czci jego matki z okazji jej pogrzebu ${ }^{5}$. Pierwszoplanową postacią nie jest w nim on, lecz ona, przy czym autor uzupełnia niektóre dane, dotyczące zwłaszcza dzieciństwa Teodora, które są zawarte tylko w tej pozycji.

Historia Kościoła

\section{Główne wątki tematyczne Mowy pogrzebowej}

$\mathrm{Na}$ wstępie naszych rozważań trzeba zaznaczyć, że celem niniejszego studium będzie curriculum vitae Teoktysty. Nie oznacza to wszakże, iż skupiając uwagę przede wszystkim na jej osobie, pominiemy zupełnie treści odnoszące się do Teodora. Przemawiają za tym istniejące między nimi ścisłe więzy, wynikające z osobistych relacji, pogłębiających się pod wpływem przeżywanych wspólnie wydarzeń, zarówno tych w domu rodzinnym w Konstantynopolu, jak i późniejszych, gdy prowadzili obydwoje życie zakonne. Ponadto można tu jeszcze dodać, że ich losy przenikały się wzajemnie do tego stopnia, iż trudno byłoby zrozumieć ważne decyzje podejmowane przez Teodora, zwłaszcza w młodości, bez wcześniejszego wpływu na nie jego matki. Ona pierwsza wprowadziła go m.in. w bogaty świat Biblii, uczyła umiłowania modlitwy, czy też praktykowania ascezy ${ }^{6}$. Warto wspomnieć,

$4 \quad$ Por. Mate Katechezy: PG 99, 509-688; Sancti Theodori Studitae sermones parvae catcheseos, J. Cozza-Luzi (red.), [w:] A. Mai, Nova Patrum Bibliotheca (=NPB), t. 9/1, Roma 1888; Sancti Patris nostri Confessoris Theodori Studitis praepositi parva catechesis, E. Auvray (red.), Parisiis 1891; Wielkie Katechezy: Sancti Theodori Studitae sermones magnae catcheseos, J. Cozza-Luzi (red.), [w:] A. Mai, NPB, t. 9/2, Roma 1888 i t. 10/1, Roma 1905; Listy: Epistularum libri duo, PG 99, 904-1669 lub G. Fatouros (red.), [w:] Corpus Fontium Historiae Byzantinae, 31/1-2, Berlin - New York 1992; zob. także: utwór pochwalny ku czci Platona: Laudatio S. Platonis archimandritae, PG 99, 804-849.

Por. Laudatio funebris in matrem suam, PG 99, 884-902. Zob. Stownik tacińsko-polski, opr. K. Kumaniecki, Warszawa 1999 (słowo łacińskie laudatio = m.in. mowa pogrzebowa), s. 248. W niniejszym artykule utwór Laudatio funebris in matrem suam (Mowa pogrzebowa ku czci swojej matki) jest tłumaczeniem własnym i w języku polskim będzie posiadał skrócone, następujące brzmienie: Mowa pogrzebowa lub Mowa. Godne uwagi jest także opracowanie poświęcone Teoktyście: B. Hermann, Theoktista aus Byzanz, die Mutter zweier Heiligen Theodorus Studites, Freiburg 1919.

Por. Laudatio funebris in matrem suam 4, PG 99, PG 99, 888ABC. 
że Mowa pogrzebowa, będąca głównym źródłem poznania Teoktysty, była skierowana przez Teodora do mnichów studyjskich w miejsce konferencji ascetycznej, jaką zwykle wygłaszał dla ich duchowego pożytku ${ }^{7}$. Już w pierwszym rozdziale tej Mowy, Teodor, jako przełożony wspólnoty zakonnej, oznajmia swoim współbraciom nieoczekiwaną wiadomość o nagłej śmierci Teoktysty, postaci dobrze im znanej, a zarazem rodzonej siostrze „,naszego wspólnego ojca” Platona ${ }^{8}$. Najpierw św. Teodor stwierdza, że jego zadanie będzie polegało na przekazaniu tylko faktów, bez uciekania się do jakiejkolwiek zbędnej przesady, która mogłaby doprowadzić do zniekształcenia jej curriculum vitae pełnego zasług ${ }^{9}$. Następnie podkreśla, iż pomija prawie zupełnym milczeniem historię dzieciństwa i młodości Teoktysty, rozpoczynając swoją narrację od jej wyjścia za mąż i kontynuuje ją aż do momentu zgonu. Z kolei przyznaje, że lata poprzedzające jej zamążpójście, z oczywistych poHistoria Kościoła wodów, nie były mu osobiście znane. Zapewnia jednak, iż zależnie od potrzeby, będzie niekiedy do nich wracał, gdyż w jego przekonaniu, przyczyni się to do jej lepszego poznania i pozwoli pełniej zrozumieć, jak na przestrzeni mijającego czasu rozwijało się jej życie duchowe ${ }^{10}$.

Odnośnie tekstu zawartego w Mowie pogrzebowej, będącej przedmiotem naszego zainteresowania, to wydaje się nam, że można go podzielić na dwie zasadnicze części. Pierwsza z nich obejmuje okres czasu, jaki Teoktysta spędziła w Konstantynopolu u boku swojego męża Fotyna, gdzie zajmowała się prowadzeniem domu i gospodarstwa oraz wychowaniem dzieci ${ }^{11}$. Druga zaś część związana jest z brzemienną w skutki decyzją, jaką podjęła po około 23 latach trwania ich związku małżeńskiego w roku 780 lub $781^{12}$, wypełnionego wewnętrzną walką ze swoim macierzyńskim sercem i chrześcijańskim sumieniem. Zakończyła się ona opuszczeniem męża (za jego zgodą) oraz niepełnoletnich jeszcze dwóch synów (Józefa i Eutymiusza) oraz Teodora (który prze-

Por. tamże 1, PG 99, 884B.

Tamże 1, PG 99, 884A.

Por. tamże 1, PG 99, 884AB.

Por. tamże 2, PG 99, 884BC.

Por. tamże 2-6, PG 99, 884C-892A.

Uważamy, że nastąpiło to wkrótce po śmierci cesarza ikonoklasty, Leona IV Chazara (775-780). Taki wniosek można wyprowadzić na podstawie Mowy pogrzebowej, w której Teodor Studyta nie wymienia imienia tego władcy, ani jego dwóch poprzedników: Leona III Izauryjczyka (717-741) i Konstantyna V Kopronima (741-775), zwalczających bardziej niż on kult świętych obrazów i jego zwolenników. Por. Laudatio funebris in matrem suam 8, PG 99, 892D. Zob. T. E. Gregory, Historia Bizancjum, tłum. J. Hunia, Kraków 2008, s. 186-199. 
Historia Kościoła

kroczył wówczas 18 rok życia) i poświęceniem się na wyłączną służbę Bogu we wspólnocie ascetek ${ }^{13}$.

Trudno nie przyznać, że bardzo cenne informacje o Teoktyście, pochodzą szczególnie z okresu młodości Teodora. Był on wtedy nie tylko naocznym świadkiem wielu ważnych szczegółów zaczerpniętych z jej życia, Fotyna i rodzeństwa, ale je wraz z nimi współtworzył. Jednakże wiedzę o tym, co działo się przed jego urodzeniem oraz w latach wczesnego dzieciństwa, czerpał zapewne w pierwszej kolejności od swoich rodziców, wuja Platona lub innych krewnych. Analogiczna sytuacja, odnośnie zbierania przez niego danych o Teoktyście, zwłaszcza za panowania cesarza Konstantyna VI (780-797) ${ }^{14}$, zaistniała również i wówczas, gdy był on mnichem, lecz z pewną różnicą. Polegała ona na poszerzeniu grona osób o przyjaciół i znajomych, a także anonimowych świadków, mających z nią jakikolwiek kontakt. Dzięki tak szeroko zakrojonej akcji informacyjnej, mógł łatwiej zlokalizować miejsce jej aktualnego pobytu. Było ono bowiem często uzależnione m.in. od tego, gdzie zatrzymywał się konwój żołnierzy wraz z Teodorem i jego mnichami (idącymi do Tesaloniki, 796 r.), internowanymi z powodu obrony świętych obrazów. Towarzyszyła im Teoktysta, która spotykała się niekiedy z nimi potajemnie podczas nocnych postojów, będąc sama zagrożona wydanym na nią podobnym wyrokiem.

\section{Asceza Teoktysty $\mathrm{w}$ ramach życia rodzinnego}

W niniejszym rozdziale pragniemy skupić się na zagadnieniu życia ascetycznego Teoktysty, które prowadziła w Konstantynopolu, stolicy Cesarstwa Wschodniego, jako żona Fotyna, nie zaniedbując przy tym swoich obowiązków matki i gospodyni domowej. Należy tu wspomnieć, że Teodor wywiązując się z obietnicy złożonej na początku Mowy pogrzebowej, pomija milczeniem większość faktów, jakie wydarzyły się przed jej ślubem. Nie jest więc czymś zaskakującym, że nie opisuje metody wychowawczej, jaką wobec niej stosowano, czy też atmosfery religijnej, w której wzrastała. Ogranicza się jedynie do ogólnego stwierdzenia, mówiącego „o cennych wartościach moralnych” ${ }^{15}$, jakie przekazali jej rodzice. Nie wymienia jednak ani ich imion, ani imion rodzeństwa, za wyjątkiem Platona. Nie oznacza to bynajmniej, że jesteśmy zdani na same hipotezy, niemające żadnego potwierdzenia w Mowie pogrzebowej. W niej bowiem znajduje się wzmianka, zapew-

\footnotetext{
13 Por. Laudatio funebris in matrem suam 7-13, PG 99, 892B-900D.

14 Por. tamże 8-10, PG 99, 893A-897A.

15 Tamże 2, PG 99, 884B.
} 
niająca nas m.in. o tym, że Teoktysta kochała Boga całym sercem i wyrażała to w licznych praktykach religijnych, zarówno przed, jak i po ceremonii ślubnej z Fotynem. Powyższe stwierdzenie, odnoszące się do jej nadprzyrodzonej cnoty miłości do Stwórcy, obejmuje więc również okres, gdy była jeszcze panną. Wydaje się nam, że zarówno uczucie, jakim darzyła Boga, jak i wyrażenie wiary w formie kultu, są wymownym świadectwem pobożności, którą wyniosła najprawdopodobniej z rodzinnego domu. Wartości te przekazała następnie swoim dzieciom i wywarła decydujący wpływ na kształtowanie się osobowości córki i trzech synów oraz na ich pozytywny stosunek do życia ascetycznego. Nie jest to odosobniony przykład, wskazujący na jej związki ze środowiskiem, w którym pielęgnowano zwyczaje chrześcijańskie. Znalazło to swój wyraz w jej postępowaniu po urodzeniu każdego z czworga dzieci, które oddawała pod opiekę Bogu, czyniąc nad nimi znak życiodajnego krzyża, dającego zbawienie. Natomiast zupełnie inne było zachowanie się jej sąsiadek, które wypowiadały zaklęcia nad swymi nowo narodzonymi niemowlętami za „radą demonów”" Czyniły też czary nad miejscami przeznaczonymi do siedzenia i łóżkami, przywiązując do nich przepaski, naszyjniki i amulety, mające zapewnić ich potomstwu obronę przed nieszczęściem. Teodor Studyta nie szczędzi w tym miejscu pochwał pod adresem Teoktysty, za jej zdecydowaną postawę odmowy wzięcia udziału w tego rodzaju zabobonach ${ }^{17}$. Nie sposób tu nie odnotować informacji, pochodzącej z okresu dzieciństwa matki Teodora, w której podjęte zostało zagadnienie jej edukacji. Otóż kiedy była w wieku szkolnym, nie uczestniczyła w zajęciach lekcyjnych (podobnie jak jej rówieśniczki) ${ }^{18}$ pod okiem wynajętego przez rodziców nauczyciela, jak to było np. w przypadku jej syna Teodora ${ }^{19}$. Dlatego tym bardziej godna podziwu była jej postawa, pełna determinacji w nadrabianiu zaległej wiedzy. Nastąpiło to jednak dopiero wtedy, gdy

16 Tamże 2, PG 99, 884C. Fragment ten można również przetłumaczyć w sposób następujący: ,pod wpływem diabelskiego poruszenia”.

17 Por. tamże 2, PG 99, 884C-885A.

18 Por. tamże 3, PG 99, 885B. Zob. H. Evert-Kappesowa, Historie konstantynopolitańskie, Łódź 1988, s. 94: „Miała trzech synów i córkę. Dziewczynkę, gdy tylko podrosła, poczęła wdrażać do zajęć domowych, uczyła ją tkać, szyć, śpiewać psalmy, zabierała ze sobą na dobroczynne wizyty [...]. Edukacja jej w dzieciństwie była dosyć zaniedbana. Aby więc nadrobić braki musiała zdobyć się na ogromny wysiłek i niejedną noc przesiedzieć nad książką".

19 Na ten temat pisze Teodor Dafnopat w biografii poświęconej św. Teodorowi Studycie. Por. Vita et conversatio S. Theodori Studitae A 2, PG 99, 117C. Zob. H. Evert-Kappesowa, Historie konstantynopolitańskie, dz.cyt., s. 94: „Chłopców natomiast posyłała do szkoły z chwilą, gdy kończyli siódmy rok życia”. 
Historia Kościoła

zaczęła w niej wzrastać miłość do Boga, która pogłębiła się jeszcze bardziej w małżeństwie. Była ona decydującym impulsem, dzięki któremu dosyć dobrze i szybko opanowała na pamięć Księgę Psalmów. Trzeba przyznać, że Teoktysta w swoim dążeniu do zjednoczenia z Bogiem, starannie dobierała odpowiednie środki, prowadzące do osiągnięcia wyznaczonego przez siebie celu. Jednym z nich było codzienne czytanie Pisma Świętego, na które znajdowała czas, mimo licznych obowiązków związanych z wychowaniem dzieci i prowadzeniem domu. Oddawała się temu zajęciu późnym wieczorem i wczesnym rankiem, wykonując jednocześnie ręczne prace, z obawy, by nie przynieść uszczerbku gospodarstwu przez swoją bezczynność i nie być powodem strapienia dla męża. Od tej chwili, matka Teodora, nie tylko dniem, ale także i nocą rozważała natchnione przez Ducha Świętego Psalmy oraz inne teksty Starego i Nowego Testamentu, jak również literaturę ascetyczną. Przyczyniło się to do powstania w jej sercu tęsknoty za rzeczywistością niewidzialną, w której przebywa Bóg. Z dalszej relacji Teodora można też dostrzec, jak rozwijało się jej życie duchowe. Polegało ono na wyrzeczeniu się wielu przyjemności, jakie proponował otaczający ją świat. Nic więc dziwnego, że zaproszona na ucztę weselną, kierowała się powściągliwością w przyjmowaniu pokarmów, unikając potraw mięsnych. Bogaty zaś program rozrywkowy, przygotowany zwykle na tego rodzaju uroczystość, nie wzbudzał w niej żadnego zainteresowania. W czasie Wielkiego Postu nie spożywała dań zawierających mięso, ani jego przetworów, zaś w innych okresach roku liturgicznego, konsumowała je w małych ilościach. Do wyżej wymienionych ćwiczeń ascetycznych, należy zaliczyć odpowiedzialność za wypowiadane przez nią słowa. Warto odnotować fakt, że niemal pokutny sposób jej życia, zrobił tak duże wrażenie na znających ją mieszkańcach Konstantynopola, że stała się dla nich wzorem do naśladowania. Postronny zaś obserwator, słysząc o tak heroicznej postawie, a nie znając jej osobiście, mógłby dojść do wniosku, że jest ona raczej wdową, niż kobietą mającą męża i dzieci. Teodor stwierdza, że do końca życia była wierna przysiędze, jaką złożyła Fotynowi podczas ceremonii ślubnej i posiadała tak czystą duszę, że nie dopuszczała do siebie nawet myśli naruszającej swoje zobowiązanie ${ }^{20}$. Odznaczała się również cnotą wdzięczności wobec Boga i uważała, że każda pora dnia i nocy była stosowna, by składać dziękczynienie za Jego dary. Nie zaniedbywała przy tym obowiązków związanych z prowadzeniem domu, hojnie wspierając ubogich, a swoją postawą pełną energii i przedsiębiorczości, twórczo wpływała na dzieci, służące i męża. Usil-

Por. Laudatio funebris in matrem suam 3, PG 99, 885BC. 
nie troszczyła się o rozwój jego życia duchowego, przypominając mu o nadchodzącej i nieuniknionej śmierci. Zachęcała go do powstrzymania się od pożycia małżeńskiego i skutecznie przekonała do tego na okres pięciu lat, chociaż nadal dzielili wspólne łoże, co w opinii Teodora było zjawiskiem rzadko spotykanym. W dalszej części tego opisu, Teodor wyraża się z podziwem o swoich rodzicach w następujących słowach: czyż nie jest to zdumiewający fakt, „gdy ogień nie może się zbliżyć do leżącej w pobliżu słomy?"21. Pragnie też podkreślić, że taki przypadek miał miejsce $\mathrm{w}$ zamierzchłej przeszłości i nawiązuje do analogicznego przykładu ze Starego Testamentu, przywołując postać Booza, który otrzymał pochwałę za jedną noc, podczas której pozostał beznamiętny w stosunku do Rut, śpiącej u jego nóg (por. Rt 3, 7-14). Teodor uważa, że za okresową wstrzemięźliwość Fotyna i Teoktysty, należy się im obojgu szacunek, gdyż zarówno on, jak i ona, mają w tej materii taką samą zasługę. Trzeba przyznać, że Teoktysta troszczyła się nie tylko o dobro duchowe Fotyna, lecz otaczała także macierzyńską miłością swoje dzieci. Jej aktywność na tym polu polegała głównie na wychowaniu córki i synów poprzez dawanie im uwag i przestróg oraz stosowanie metody rozsądnego karcenia, kierując się jedynie pragnieniem doprowadzenia ich do ewangelicznej doskonałości. Teodor zaznacza, że wśród wielu wspomnień wyniesionych z rodzinnego domu, z lat dzieciństwa i wczesnej młodości, ważne były zwłaszcza te, które przyczyniły się do religijnego rozwoju jego i rodzeństwa. Główną rolę w tym procesie odegrała Teoktysta, która wieczorem, przed nocnym spoczynkiem, czyniła nad każdym z nich znak krzyża, a po przebudzeniu przyzwyczajała do codziennej, wspólnej modlitwy porannej. Najwięcej czasu poświęcała córce, nie pozwalając jej patrzeć na mężczyzn, ani przyozdabiać się naszyjnikami i bransoletkami, czy też nosić purpurowych płaszczy. Stwarzała zaś odpowiednie warunki, sprzyjające rozwojowi jej pobożności, poprzez studium Pisma Świętego i literatury o tematyce religijnej. Aby czytane przez nią teksty nie rozpoczynały się i nie kończyły w sferze teoretycznych rozważań, uczyła ją przyjmować biednych i zmuszała, by własnymi rękoma oczyszczała rany chorych. Odwracała też jej myśli od spraw doczesnych i kierowała je ku nadprzyrodzonemu pięknu i w końcu poświęciła ją na wyłączną służbę Bogu ${ }^{22}$. Cechowało ją również wyjątkowo życzliwe podejście do sług i służących, których traktowała niemalże jak domowników, co wyróżniało ją w tej kwestii od innych zamożnych obywateli Konstantynopola. Osoby wykonujące służebne prace u bogatych mieszkańców

21 Tamże 4, PG 99, 888A.

22 Por. tamże 4, PG 99, 885D-888ABC. 
Historia Kościoła

tego miasta, otrzymywały zwykle proste pożywienie, składające się z chleba, wina i jarzyn. Teoktysta zaś dosyć często, a szczególnie w dni świąteczne, podawała im świeże mięso, ryby, ptactwo i smacznie przygotowane napoje, gdyż nie chciała spożywać tych potraw tylko w wąskim gronie rodzinnym ${ }^{23}$. Trudno nie odnotować faktu, że nie mniej niż o zaspokojenie podstawowych potrzeb egzystencjonalnych, takich jak: pokarm czy odzież, troszczyła się o wyeliminowanie nadużyć związanych z naruszeniem szóstego i siódmego przykazania Bożego, $\mathrm{u}$ pracujących u niej dziewcząt oraz o nabycie potrzebnych dla nich cnót. Aby osiągnąć wysoki poziom moralny każdej z nich, stosowała różne formy nacisku, nie wyłączając gróźb, a nawet użycia siły fizycznej w postaci wymierzenia kary cielesnej. Przekonana zaś o słuszności wzniosłej misji powierzonej jej przez Boga wobec podopiecznych, nie zawsze stawała na wysokości zadania, gdyż będąc z natury porywczą, nie była w stanie opanować uczucia gniewu oraz okazywała się zbyt surowa, co nie ułatwiało życia zarówno jej, jak i Fotynowi. Teodor podejmując się próby oceny takiego postępowania swojej matki, najpierw gani ją za niewłaściwy dobór metod wychowawczych. Następnie stara się usprawiedliwić jej zachowanie, motywując je tym, że kierowała się przede wszystkim gorliwością o chwałę Bożą oraz nie mogła znieść łamania Dekalogu, przez co Bóg był obrażany. Z kolei chwali ją za to, że po sprawieniu przykrości i zadaniu bólu, zdobywała się na szczery żal i skruszona zapraszała do siebie osobę poszkodowaną, padała przed nią na kolana, prosząc o wybaczenie. W ten sposób zjednywała sobie nawet brutalnie potraktowane dziewczęta, które potrafiły docenić jej szlachetne intencje pełne bojaźni Bożej i troski o ich dobro, za co darzyły ją nieskrywaną miłością ${ }^{24}$. Działalność Teoktysty nie ograniczała się tylko do zaspakajania duchowych i materialnych potrzeb osób znajdujących się w jej najbliższym otoczeniu. Posiadane przez nią środki umożliwiały jej podjęcie aktywności dobroczynnej również wśród przychodzących do niej po jałmużnę ubogich mieszkańców stolicy oraz przybyłych do niej z różnych powodów gości. Teodor opisując poświęcenie, z jakim Teoktysta była oddana dziełom miłosierdzia, wyznaje, że nie znał innej takiej kobiety, która by przewyższała ją w miłości do potrzebujących. Odznaczała się bowiem wobec nich wyjątkowym współczuciem, unikając przy tym rozgłosu, a dzięki cnocie pokory nie przywiązywała wagi zarówno do negatywnych opinii, jak i pochwał, wypowiadanych pod jej adresem. Wśród wielu świadków potwierdzających taki stan rzeczy, można wymienić

23 Por. tamże 5, PG 99, 888C.

24 Por. tamże 5, PG 99, 888D-889A. 
sieroty i wdowy z Konstantynopola i jego okolic, nie wyłączając z tego grona chorych oraz starców, osobiście przez nią pielęgnowanych. Czynnikiem decydującym o otwartości Teoktysty wobec ludzi szukających u niej wsparcia, była niewątpliwie jej nadprzyrodzona wiara. Była ona dla niej argumentem przynaglającym ją do przyjmowania ich do swojego domu, zwłaszcza w dni świąteczne. W ich zaś osobach gościła samego Chrystusa, który w ubogich zasiadał wraz z nią do stołu i był jej współbiesiadnikiem ${ }^{25}$. Ponadto jej dusza była przeniknięta na wskroś miłością do życia ascetycznego, i to do tego stopnia, że stała się jego propagatorką, przekonując do praktykowania go swojego męża. Podobny cel osiągnęła także w stosunku do swoich dzieci, które zdołała przychylnie usposobić do wszelkiego rodzaju wyrzeczeń, dzięki wygłaszanym naukom, zawierającym pouczenia i obietnice przyszłej szczęśliwości. Po pewnym czasie dołączyło do tego grona trzech braci Fotyna, do czego wydatnie przyczyniła się również Teoktysta ${ }^{26}$.

\section{Uczta pożegnalna i rozstanie $\mathrm{z}$ rodziną}

W poprzednim rozdziale niniejszego artykułu, przedstawione zostało życie ascetyczne Teoktysty, które prowadziła w gronie rodzinnym, jako matka, żona i gospodyni domowa. Poniżej pragniemy ukazać skutki jej decyzji, polegające na opuszczeniu męża i dzieci i rozpoczęciu nowego etapu życia poświęconego na wyłączną służbę Bogu wraz z nieliczną grupą bliskich sobie i podobnie myślących kobiet. Wiadomość ta stała się wydarzeniem, które wprawiło w podziw mieszkańców stolicy. Zdumiało zwłaszcza jej krewne, zdziwiło znajomych i wprowadziło zamieszanie wśród świadków tak radykalnej decyzji, a także wywołało pewne poruszenie obywateli, znających tę sprawę tylko z przekazu ustnego. Jednakże taka reakcja wielu środowisk Konstantynopola miała swoje uzasadnienie, ponieważ „Teoktysta i Fotyn byli wówczas jeszcze w średnim wieku"27 i żyli w dobrobycie. Ponadto rodzina ta cieszyła się powszechnym szacunkiem, gdyż Fotyn pełnił służbę na dworze cesarskim, piastując wysokie stanowisko w urzędzie podatkowym. Inną przyczyną budzącą pewien niepokój wśród obywateli stołecznego miasta był fakt, że małżonkowie ci, chociaż mieli trzech synów, nie powstrzymali się przed podjęciem trudnej decyzji i nie pozostawili potomka płci męskiej, kontynuującego przedłużenie istnienia ich rodu, albowiem wybrali oni wszyscy życie w celibacie. Wiele komentarzy

25 Por. tamże 5, PG 99, 889AB.

26 Por. tamże 6, PG 99, 889BC.

27 Tamże 6, PG 99, 889C. 
Historia Kościoła

wywołała także ich rezygnacja ze światowych przyjemności. Nie bez echa pozostało zerwanie przez nich więzi rodzinnych, czy też oddanie domu na rzecz ubogich oraz obdarzenie wolnością służących; nie mówiąc już o wyrzeczeniu się cesarskich godności i porzuceniu prestiżowego zawodu, będącego w sferze marzeń wielu osób wywodzących się z zamożnych rodów. Teodor, jako uważny obserwator, znajdujący się w centrum tych wydarzeń, stwierdza, że pomysłodawcą i wykonawcą powyższych idei była Teoktysta. Chwali ją za męstwo i nieugiętość w doprowadzeniu do celu szlachetnych planów i porównuje do postawy, jaką odznaczał się Abraham (por. Rdz 22, 1-18). Zalicza ją także do grona kobiet razem z matką Machabeuszy (por. 2 Mch 7, 20), ponieważ złożyła swoje dzieci na ofiarę ascetycznych zmagań. Uważa, że zacho-

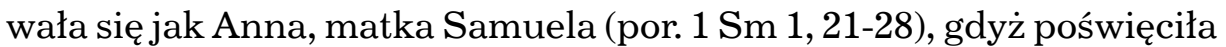
Bogu nie jeden, lecz każdy z czterech owoców swego łona ${ }^{28}$.

Godna uwagi jest zwłaszcza relacja Teodora, odnosząca się do pożegnalnego spotkania Teoktysty z zaproszonymi przez nią krewnymi. Wśród osób przybyłych wówczas do jej domu, można było dostrzec, że byli pogrążeni w bólu i płakali. Warto podkreślić, że świadkowie tej uroczystości, patrząc na zdumiewający widok dobrowolnego oddalenia się Teoktysty od świata pełnego przepychu oraz poddając ocenie wielkość tego niezwykłego wydarzenia, byli pełni podziwu, nie szczędząc pochwał pod jej adresem ${ }^{29}$. W tym historycznym momencie dla całej rodziny brał udział Teodor oraz Platon, jak również postronni mieszkańcy Konstantynopola, dla których było to zjawisko tak wyjątkowe, że przybyli na nie, chociaż nie byli zaproszeni ${ }^{30}$. Bez wątpienia tego rodzaju uroczystości, dostarczają zwykle jego uczestnikom wielu niezapomnianych i wzruszających przeżyć, co miało miejsce i w tym przypadku. Spotkanie to przyniosło jednak jeszcze dodatkowo, niespodziewanie błogosławione owoce, w postaci powołania niektórych jego uczestników do życia poświęconego na wyłączną służbę Bogu. Byli to nieznani z imienia mężczyzna i kobieta. O niej wiemy tyle tylko, że nie od razu została ascetką, lecz po pewnym czasie, rozdając przedtem swój majątek potrzebującym.

Kontynuując swoje opowiadanie Teodor zaznacza, że z małżeńskiego etapu życia Teoktysty w Konstantynopolu, a zwłaszcza z pamiętnego dnia rozstania z rodziną, powinni odnieść duchowy pożytek nie tylko mnisi, ale również i ludzie świeccy ${ }^{31}$. Kładzie akcent szczególnie na

Por. tamże 6, PG 99, 889CD.

Por. tamże 6, PG 99, 889D-892A.

Por. tamże 7, PG 99, 892B.

Por. tamże 6, PG 99, 892A. 
podjęte przez nią wyrzeczenia, będące ozdobą jej duszy i prowadzące do wewnętrznej przemiany oraz anielskiego sposobu życia, czyli do życia monastycznego. Już na początku tej drogi pojawiły się trudności, spowodowane rozłąką z mężem i synami. Ich zapowiedź znajdujemy w wypowiedzi Teodora, piszącego pod wpływem decyzji matki o towarzyszących mu jednocześnie uczuciach radości i smutku. Wyznaje, iż nie potrafi wskazać, które z nich było w jego odczuciu dominujące ${ }^{32}$. Nawiązując do poprzedniego zdania, pragniemy odnieść się jeszcze do zawartych w nim dwóch słów, a zwłaszcza do pierwszego z nich, gdyż jego użycie w tak trudnej sytuacji rodzinnej, budzi uzasadnione wątpliwości. Najpierw skupimy się więc na nim, by ustalić, jaka była przyczyna umieszczenia go w tym kontekście. Teodor Studyta, ku naszemu zaskoczeniu, nie podaje na ten temat żadnej informacji. $\mathrm{W}$ takim stanie rzeczy, podjęliśmy próbę opracowania własnej hipoHistoria Kościoła tezy i doszliśmy do wniosku, że część odpowiedzi na to pytanie, znajduje się w przeprowadzonych wyżej rozważaniach. Otóż uważamy, że uczucie radości było przeżywane, a następnie przelane na papier przez Teodora, na podstawie posiadanej przez niego wiedzy, o wielkim pragnieniu jego matki, która będąc mężatką, prowadziła głębokie życie wewnętrzne i przez długie lata przebywania w tym stanie, nosiła się z zamiarem, by zostać mniszką. Wydaje się, że zaproponowany wyżej argument, byłby dla niego, jako syna, chociaż wtedy już pełnoletniego, trudny do zaakceptowania w obliczu rzeczywistości rozstania, gdyby on sam nie praktykował licznych umartwień i nie cenił tego sposobu życia oraz nie odnosił się do niego z podobnym pietyzmem, jaki żywiła i Teoktysta. Należy wspomnieć, iż obok radości, towarzyszył Teodorowi równocześnie i smutek, który przenikał także dwóch jego braci. Dlatego w ich imieniu i własnym, odniósł się do przeżywanego przez nich dramatu, polegającego na zbliżającym się, nieuchronnym i bezpowrotnym wyjeździe najbliższej dla nich osoby. Ogrom bólu obecny w ich sercach, ujął w następujących słowach: „utraciliśmy matkę i już nie mogliśmy z taką śmiałością, jak dawniej, gaworzyć z nią i przychodzić do niej"33. Po opuszczeniu domu przez Teoktystę, Teodor, wraz z ojcem Fotynem, zamierzał uczynić to samo, co ona. Nie ukrywał, że nie mógł sobie poradzić z tak trudnym doświadczeniem, jakiego nie oszczędził mu los $\mathrm{w}$ tak młodym wieku. Wypada jeszcze zauważyć, iż Teodor przelał na papier również uwagi, dotyczące dosyć spektakularnego zachowania się swojego najmłodszego brata, Eutymiusza, który był w dniu rozstania z Teoktystą jeszcze młodzieńcem.

$32 \quad$ Por. tamże 7, PG 99, 892B.

33 Tamże 7, PG 99, 892B. 
Nie chciał pogodzić się z tak brzemiennym dla niego w skutkach faktem, dlatego zaczął przekonywać oraz usilnie prosił matkę o przesunięcie terminu wyjazdu. Gdy pierwsza próba zatrzymania jej nie powiodła się, wówczas zawodził, obejmował ją, przy czym biegał, rzucał się na szyję i nie odchodził od niej ani na krok. Zachowywał się jak młode cielę, obawiające się rozłąki oraz błagał, aby na krótki czas pozostawiono go u niej, a po zrealizowaniu tej prośby obiecał, że spełni jej wolę i powróci do rodzinnego domu. Wydawało się, że emocje wyrażone przez Eutymiusza, obudzą w jej sercu macierzyńskie uczucia i skłonią do pewnych ustępstw. Trzeba przyznać, że była to wyjątkowo dogodna chwila, która została wykorzystana przez niego, jako argument, mogący wpłynąć na zmianę jej decyzji. Istniała więc jeszcze nadzieja, że radykalny plan Teoktysty, mający swoje ascetyczne podłoże, będzie odroczony w czasie. Przemawiała za tym także opinia Fotyna, uważającego, że był on przeprowadzony za wcześnie, z powodu młodocianego wieku córki i dwóch synów, co łatwo można wykazać, chociażby na podstawie zachowania się Eutymiusza. Trudno jednak podejrzewać Teoktystę, jako kobietę odznaczającą się roztropnością, aby na długo przed podjęciem tak ważnej decyzji nie rozważyła tego zagadnienia i nie liczyła się z oczywistymi konsekwencjami wyboru nowej drogi życiowej, prowadzącej jeśli nie do zerwania, to na pewno do poważnego zakłócenia więzi rodzinnych. Świadczy o tym dialog, do jakiego doszło między nią a Eutymiuszem, w którym, jak zaznacza Teodor, nie zachwiało się jej niezłomne serce i nie skłoniło do zmiany zdania oraz nie ugięło się wobec błagalnych łez syna. Tłumiąc zaś wzruszenie powiedziała: „Jeśli ty, dziecko, nie pójdziesz dobrowolnie, to ja osobiście zaprowadzę cię do świątyni" " ${ }^{34}$. Słowa te okazały się na tyle skuteczne, iż Eutymiusz ustąpił w obecności rodziców oraz rodzeństwa. W przekonaniu Teodora, Teoktysta dzięki swojej heroicznej postawie, dokonała czegoś podobnego, co porównuje on z czynem świętej matki jednego z 40 męczenników z Sebasty, w Armenii, która swojego ledwie żyjącego syna, położyła przed oprawcami, by go stracono przez łamanie kości na kole ${ }^{35}$.

\section{Życie ascetyczne Teoktysty we wspólnocie mniszek i podczas prześladowań}

Należy zaznaczyć, że po pokonaniu wielu trudności, otwierała się przed Teoktystą długo oczekiwana, nowa perspektywa, pozwalająca

Tamże 7, PG 99, 892C.

Por. tamże 7, PG 99, 892BCD. 
realizować ideały ascetyczne. Aby wcielić je w życie, konieczne było do tego nie tylko umiłowanie życia zakonnego, lecz również odpowiednie miejsce w postaci klasztoru. Ten drugi postulat, tak istotny, był zagrożony niemalże od samego początku, z powodu prześladowań wyznawców świętych obrazów, do których zaliczała się Teoktysta. Była ona co prawda świadoma sytuacji politycznej, w jakiej żyła. Jednakże pomimo istniejących przeszkód, żywiła nadzieję, że zgromadzi wokół siebie wiele kobiet, pragnących tak jak ona, oddać się na wyłączną służbę Bogu. Rzeczywistość okazała się do tego stopnia złożona, że zmuszona była odłożyć swoje plany na czas bliżej nieokreślony, gdyż nawet po śmierci cesarza ikonoklasty, Leona IV Chazara, jego zwolennicy byli nadal na tyle silni i aktywni, że utrudniali skutecznie realizację ascetycznych ideałów ${ }^{36}$. W tak trudnym momencie dla powstającej wspólnoty, skorzystała z rady swojego brata Platona. Zachęcał on ją do tego, by zamieszkała razem z krewną oraz swoją niepełnoletnią jeszcze córką, postrzyżoną już nieco wcześniej i wprowadzoną w życie ascetyczne, które rozpoczęła w domu rodzinnym pod bacznym okiem matki. W tym okresie Teoktysta boleśnie odczuwała nie tylko brak stałego kierownictwa duchowego, lecz doświadczyła wiele przykrości ze strony swoich przeciwników, którzy nie przebierając w środkach, zdołali usunąć ją z sanktuarium, gdzie oddawała się modlitwie ${ }^{37}$.

Teodor wspomina także o kolejnym dotkliwym utrudnieniu, uniemożliwiającym prowadzenie życia zakonnego przez Teoktystę, które miało miejsce za panowania cesarza Konstantyna VI. Główną zaś przyczyną prześladowań, był jej sprzeciw wobec powtórnego i cudzołożnego związku tegoż władcy z jej krewną Teodotą (795 r.). Informuje nas o tym Teodor, ubolewając nad tym i wyznając ze wstydem, że do grona osób, które wystąpiły przeciwko Teoktyście, należeli nie tylko urzędnicy dworu cesarskiego, lecz również członkowie ich rodziny. $Z$ tego powodu sytuacja trzyosobowej wspólnoty ascetek stała się dramatyczna, gdyż zostały pozbawione nie tylko dachu nad głową, lecz i pewności jutra. Godne odnotowania jest i to, że Teoktysta, znajdując się nawet $\mathrm{w}$ tak trudnym położeniu, cierpliwie znosiła liczne przeciwności, nie szczędząc zdrowia dla dobra słusznej sprawy, prowadząc jednocześnie głębokie życie wewnętrzne. Na podstawie badanej przez nas Mowy pogrzebowej, wydaje się, że intensywne dążenie do zjednoczenia z Bogiem, pozwoliło jej przetrwać mężnie kolejne doświadczenia. Jednym z nich, wymagającym szczególnej siły ducha, było wygnanie jej syna

$36 \quad$ Por. G. Ostrogorski, Dzieje Bizancjum, tłum. H. Evert-Kappesowa, Warszawa 2008, s. 196-201. 
Historia Kościoła

Teodora, wraz z mnichami (796 r.), z klasztoru Sakudion, w którym był przełożonym. Warto zauważyć, że po otrzymaniu tej wiadomości, przybyła niezwłocznie, jak to tylko było możliwe, na miejsce ich zesłania, manifestując w ten sposób swoją solidarność z nimi oraz organizując pomoc, która zaspokoiła podstawowe potrzeby egzystencjalne internowanych cenobitów. Teodor, wyrażając się z uznaniem na temat heroicznej postawy Teoktysty, zaznacza, że ona wówczas, bardziej niż oni, należała do grona osób wymagających wsparcia i współczucia. Dodaje, że nawet w obliczu osobistego dramatu, zdołała zachować wewnętrzny pokój. W miejsce zaś wyrażeń pełnych emocji, wypowiadanych nierzadko w takich okolicznościach, nie wyartykułowała swego oburzenia, nie wybuchła płaczem, ani nie użyła gorzkich słów pod adresem prześladowców. Skupiła się przede wszystkim na zachęcaniu mnichów do mężnego znoszenia przeciwności, nie wyłączając męczeństwa oraz przestrzegając przed zdradą prawdy i opowiedzeniem się po stronie cudzołożnego monarchy. Była też dla nich wzorem do naśladowania, gdyż w czasach niepokoju nie udała się w bezpieczne miejsce i nie ograniczyła się do pouczeń i mów, podnoszących słuchaczy na duchu. Postanowiła bowiem towarzyszyć zakonnikom w ich wędrówce na miejsce zesłania, co doprowadziło jej organizm do wyczerpania $^{38}$. Teodor opisuje jedno $\mathrm{z}$ takich spotkań, gdy niezauważona przez żołnierzy, przedostała się do obozu, w którym przebywali uwięzieni. Widząc rany na ciele św. Teodora, opatrzyła je oliwą, składając dziękczynienie Bogu za to, że jej najstarszy syn i duchowe dzieci, mnisi, zostali poddani takiej próbie, ceniąc bardziej Boże przykazania, niż przyjaźń z niegodziwym cesarzem. Następnie z modlitwą na ustach i ze łzami w oczach, a jednocześnie $\mathrm{z}$ radością, odprowadziła ich na drogę kolejnego etapu zmagań. Swoim zachowaniem wywołała zdumienie wśród pobożnych świadków tego zdarzenia, uważających ją za świętą i cieszącą się szczególnym błogosławieństwem Bożym. Wkrótce po rozstaniu się ze wspólnotą św. Teodora, przygotowywała nowy scenariusz, mający na celu doprowadzić do ich ponownego spotkania. Aby zrealizować tego rodzaju przedsięwzięcie, musiała mieć bez wątpienia zaufanych współpracowników. Zapewne dzięki nim, wiedziała o ich wyjściu z Kataru do Tesaloniki i znała trasę przemarszu oraz nazwy osad, wsi i miast, wyznaczonych na noclegi. Opierając się na danych swoich informatorów, pewnego razu, oczekiwała na przybyszów w niewielkiej wiosce, żyjąc w strachu przed internowaniem. Po pokonaniu wielu przeciwności, na rozmowie z mnichami spędziła prawie całą noc, całując ich umęczone ciała i przeczuwając czekające ich wkrótce

Por. tamże 8, PG 99, 893ABC. 
biczowanie. Na wieść o planowanym rozdzieleniu ich i wywiezieniu w różne miejsca odosobnienia, skierowała do nich następujące słowa: „Dzieci, wydaje mi się, że idziecie na śmierć”" ${ }^{39}$. Zdawała bowiem sobie sprawę z tego, jak mogą być tragiczne w skutkach działania, których pomysłodawcą był cesarz Konstantyn VI. Uważała, że brak wzajemnej więzi między nimi, niesie ze sobą wiele zagrożeń, nie wykluczając odstępstwa niektórych zakonników od wyznawanych dotąd zasad ${ }^{40}$. Warto wspomnieć, że troszczyła się o nich zarówno w czasie prześladowań, jak i w latach pokoju, kiedy odwiedzała Sakudion, czy też gościła ich w swoim klasztorze. Poświęcała każdemu mnichowi wiele uwagi, podchodząc po macierzyńsku do jego osobistych problemów oraz prowadząc z nimi dialog, dzieląc się przy tym własnym doświadczeniem. Potrafiła także dostosować swoje rady do indywidualnych potrzeb duchowych synów Teodora, poprzez długie i częste rozmowy. Wywierała na nich zbawienny wpływ, gdyż nie tylko przekonywała, błagała, prosiła, lecz również leczyła rany serc, umacniała w dobrym i ratowała przed zgubnym pragnieniem powrotu do świata. Oprócz doradczyni w sprawach duchowych, pełniła też rolę kucharki, przygotowując posiłki wzmacniające ich ciała i w ten sposób była dla nich najlepszą opiekunką po Bogu. Należy dodać, że za rządów cesarza Konstantyna VI, zaspokajała również potrzeby egzystencjalne swojego brata, Platona, uwięzionego wówczas i poddawanego przesłuchaniom, groźbom i torturom. Internowanie nie ominęło także jej oraz czterech mniszek, prowadzących razem z nią życie ascetyczne. Teodor pisze, że pozbawiono je wolności na 30 dni, przy czym każda z nich została umieszczona $\mathrm{w}$ oddzielnym pomieszczeniu. Teoktysta zaś była tam do tego stopnia źle traktowana przez kobiecą służbę więzienną, że stosowane wobec niej metody zagrażały jej życiu ${ }^{41}$, co ujął on w następujących słowach: ,żywiła się chlebem utrapienia i piła ten sam kielich goryczy" ${ }^{2}$. Trzeba podkreślić, że była dla swoich współsióstr przede wszystkim duchową matką, prowadzącą je do doskonałości ewangelicznej. Obok tego odznaczała się wrażliwością na ich potrzeby materialne. Szczególnie dało się to zauważyć w czasie prześladowań, gdy potrafiła bardziej niż one odczytać je i zaspokoić, chociaż nie mieszkała razem z nimi. Ponadto wylała wiele łez płynących z troski o dalsze losy męża oraz syna Eutymiusza, zbyt związanego z nią emocjonalnie i nie radzącego sobie z twardą rzeczywistością w Sakudion. Nie ukrywała

39 Tamże 9, PG 99, 896A.

40 Por. tamże 9, PG 99, 893D-896AB.

41 Por. tamże 10, PG 99, 896BCD-897A.

42 Tamże 10, PG 99, 897A. 
też swego współczucia wobec osób, które z różnych powodów zeszły z prawej drogi, nie wyłączając z tego grona urzędników cesarskich, opowiadających się po stronie Konstantyna VI, i niepokoiła się o ich przyszłość po przejęciu władzy przez cesarzową Irenę (797- 802) ${ }^{43}$.

\section{Życie zakonne Teoktysty w czasie pokoju}

Cesarzowa Irena była matką wspomnianego monarchy, która pozwoliła na powrót z wygnania wspólnotom zakonnym do ich macierzystych klasztorów ${ }^{44}$. Nastały więc lata pokoju, umożliwiające Teoktyście realizować bez przeszkód czynną miłość wobec najbardziej potrzebujących. Odznaczała się bowiem wyjątkowym współczuciem i była zawsze go-

Historia Kościoła towa do dawania im jałmużny, posiadając serce wyniszczające się bez reszty w służbie ubogim. Wstawiała się też za proszących ją o wsparcie w różnych sprawach. Zdarzało się, że pożyczała im pieniądze, aby wybawić z kłopotu tych, którzy popadli w długi z powodu zaciągniętej pożyczki, czy znaleźli się w trudnym położeniu, jakiego nie oszczędził im los, i cieszyła się, że może udzielić im wsparcia. Często organizowała posiłki, na które zapraszała biednych i usługiwała im osobiście. W dalszej części Mowy pogrzebowej, Teodor wygłasza pochwałę jej ust, zajętych nieustannie czytaniem Pisma Świętego i trudniących się tą świętą czynnością aż do śmierci ${ }^{45}$. W podobnym tonie wyraża się o jej postawie ciała, a zwłaszcza o obolałych nogach i podniesionych rękach, zarówno w dzień, wieczorem, jak i o północy oraz o całonocnych rozmowach na temat modlitwy i o jej darze przewidywania przyszłości. Teodor nie ukrywa, że podejmowane przez nią ćwiczenia ascetyczne, doprowadziły jej organizm do osłabienia. Oprócz gorliwego uczestnictwa w nabożeństwach liturgicznych, odznaczała się również licznymi umartwieniami, m.in. nosząc stare ubranie, które nie ogrzewało jej ciała w czasie chłodu. Postępowała w tym samym duchu i wtedy, gdy zadowalała się twardym, ciasnym i krótkim łóżkiem oraz niewygodnym do siedzenia krzesłem. Godny uwagi był natomiast jej stosunek do ludzi, których oceniała nie tylko na podstawie ich zewnętrznego wyglądu. W ten sposób dążyła do zjednoczenia z Bogiem, walcząc ze sobą, ponieważ nie mogła być obojętna na potrzeby ubogich i nie potrafiła unikać z nimi kontaktu, a jednocześnie nie chciała zbyt często widywać się z mnichami św. Teodora i innymi osobami, gdyż w jej przekonaniu był to istotny element duchowości monastycznej. Dlatego

\footnotetext{
43 Por. tamże 11, PG 99, 897B.

44 Por. tamże 10, PG 99, 897A.

45 Por. tamże 11, PG 99, 897BC.
} 
rzadko opuszczała swój klasztor, a jeśli udawała się w drogę, to przede wszystkim w celu załatwienia niezbędnych spraw, związanych ze sprawowanym przez nią urzędem, jako przełożonej, przy czym i wówczas starała się zawsze zachowywać regułę zakonną. Teoktysta wykonywała też prace fizyczne, których Teodor nie wylicza, co prawda, szczegółowo, ale stwierdza, że były one na tyle ciężkie, iż jej delikatne z natury palce, stały się z czasem twarde i zmieniły swój kolor skóry. Oddawała się tym zajęciom, pracując z poświęceniem nie tylko na swoje utrzymanie, lecz przygotowywała i zaopatrywała w odzież prawie wszystkich mnichów z klasztoru swojego syna Teodora ${ }^{46}$. Uważa on, kontynuując swoje opowiadanie, że jego matka wyróżniała się wyjątkową pomysłowością i aktywnością spośród grona znanych mu kobiet. Mimo wielu zasług i cnót, jakimi się odznaczała, stawiano jej zarzut, polegający na tym, że była zbyt surowa wobec swoich współsióstr zakonnych, z czym Historia Kościoła Teodor nie do końca się nie zgadzał. W jego przekonaniu, postępowanie Teoktysty było podyktowane gorliwością o zachowanie Bożego piękna. Nie należy się więc dziwić, jego zdaniem, że jako przeorysza była wymagająca w stosunku do ascetek powierzonych jej opiece, a zwłaszcza w przypadku wypełniania ich obowiązków, i gniewała się na te, które niedbale wykonywały swoją pracę, czy też były rozproszone podczas wspólnych modlitw w chórze zakonnym. Zdarzało się niekiedy, że nie panowała nad swoimi emocjami i wówczas szturchała te, które się zdrzemnęły oraz uderzała nieposłuszne. Pomimo tak surowego traktowania, one kochały ją bardziej, niż ludzi ugrzecznionych, ponieważ w swoim postępowaniu kierowała się szlachetnym celem i była zawsze wymagająca oraz nawoływała do posłuszeństwa. Trzeba podkreślić, że po uwięzieniu Platona, dała przykład, jak należy się zachowywać, gdyż we wszystkim podporządkowywała się Teodorowi. Na znak uległości, obejmowała też jego nogi i wyznawała mu tajemnice swego serca, nie odstępując ani na krok od jego nakazów ${ }^{47}$. Teodor wyznaje, że ogarniał go wstyd, ilekroć przypominał sobie chwile, gdy z szacunkiem nazywała go „panem i ojcem”, łącząc bojaźń z miłością oraz słuchała go „nie jak matka, lecz jak dziecko”48. Oprócz tego przestrzegała zasady umiarkowania i nie jadła do przesytu. $Z$ kolei posłuszeństwo nie pozwalało jej zmniejszać jakości przyjmowanych pokarmów, chociaż sprzeciwiała się temu bardzo i nie chciała nawet o tym słyszeć. Interesujące jest to, że spożywała posiłki samotnie, najczęściej przed zachodem słońca, przy czym były to potrawy proste i niewyszukane,

$46 \quad$ Por. tamże 11, PG 99, 897CD-900A.

47 Por. tamże 12, PG 99, 900AB.

48 Tamże 12, PG 99, 900B. 
do których nie dodawała oliwy, ani nie używała wina. W określone dni, zwłaszcza świąteczne, spożywała inne dania, zadowalając się małą ich ilością. Dowodem tego, że nie była chciwa i nic nie miała, są słowa: „ani służącej, ani złota, ani srebra oraz niczego z przedmiotów tego świata"49, a tylko ubogą włosiennicę i dwa stare przykrycia. Trzeba podkreślić, że aż do samej śmierci unikała wszelkiego przepychu i przekazała Teodorowi oraz Platonowi jedynie to, co przygotowała na dzień swojego pogrzebu. W ten sposób pozbyła się wszystkiego, uwolniła się od rzeczy materialnych, a zwłaszcza przywiązania do świata i z radością z niego odeszła. Jednakże zanim to nastąpiło, wygłosiła do mnichów św. Teodora pełną życzliwości mowę, dając im zbawienne rady i błogosławieństwo dla każdego z nich, zebranych wokół niej po to, by być świadkiem jej zaśnięcia, czyli śmierci ${ }^{50}$. Po jej zgonie Teodor nazywa ją „matką i jednocześnie córką" ${ }^{51}$. Zwraca się też do niej pośmiertnie, pytając m.in. o to, gdzie obecnie przebywa? Następnie udziela na nie odpowiedzi. Powołuje się przy tym na jej dobre czyny, wykonane za życia i na ich podstawie wyprowadza wniosek, że dzięki nim zwyciężyła władcę mroków i udała się tam, gdzie nie ma chorób, smutku i wzdychania. W jego przekonaniu, znajduje się ona w miejscu, gdzie są wszyscy święci oraz zmarli mnisi św. Teodora, których tak umiłowała podczas swojego ziemskiego życia. Błaga ją również o to, by nie zapomniała o pozostających w klasztorze cenobitach św. Teodora, będących jej duchowymi dziećmi, a także o małej wspólnocie ascetek, których była przełożoną. Ponadto wierzy, że teraz będzie wstawiała się za nim jeszcze gorliwiej, kierując, utwierdzając w dobrym i ochraniając go swoją modlitwą przed popełnieniem grzechu, bezprawiem i wszelką inną napaścią ze strony złego ducha. Należy zauważyć, że Teodor jest świadomy swoich ograniczeń i słabości oraz wynikających z nich obaw o osobiste uświęcenie duszy i ciała. Nie dziwi więc fakt, że po raz kolejny zwraca się do Teoktysty, ufając, że dzięki łączącej ich duchowej więzi, otrzyma skuteczne wsparcie. Wyraża tė̇ głęboką nadzieję, że będzie mu towarzyszyła $\mathrm{z}$ nieba $\mathrm{w}$ osiągnięciu doskonałości i dzięki dobrym czynom wraz z nią i swoimi mnichami będzie przebywał po prawicy Chrystusa ${ }^{52}$.

\footnotetext{
49 Tamże 13, PG 99, 900C.

50 Por. tamże 13, PG 99, 900CD.

51 Tamże 14, PG 99, 901A.

52 Por. tamże 14, PG 99, 901AB.
} 
Celem naszych rozważań było przedstawienie biografii Teoktysty w oparciu o utwór pochwalny, napisany ku jej czci z okazji jej pogrzebu, autorstwa św. Teodora Studyty (759-826). Na wstępie zaznaczyliśmy, że jest ona pierwszoplanową postacią, przy czym narrator dostarcza również informacji o sobie. Warto wspomnieć, że Mowa pogrzebowa, będąca głównym źródłem poznania Teoktysty, była skierowana przez Teodora do mnichów studyjskich w miejsce konferencji ascetycznej, jaką zwykle wygłaszał dla ich duchowego pożytku. Najpierw Archimandryta Studionu stwierdza, iż pominął prawie zupełnym milczeniem historię dzieciństwa i młodości Teoktysty, rozpoczynając swoją narrację od jej wyjścia za mąż i kontynuuje ją aż do momentu zgonu. Z kolei przyznaje, że lata poprzedzające jej zamążpójście nie były mu znane. Zapewnia jednak, iż będzie niekiedy do nich wracał, ponieważ przyczyni się to do jej lepszego poznania. Odnośnie tekstu zawartego w Mowie pogrzebo$w e j$, to można go podzielić na dwie zasadnicze części. Pierwsza z nich obejmuje czas, jaki Teoktysta spędzała w Konstantynopolu u boku swojego męża Fotyna, gdzie zajmowała się prowadzeniem domu i gospodarstwa oraz wychowaniem dzieci. Druga zaś część związana jest z brzemienną w skutki decyzją, jaką podjęła po około 23 latach trwania ich związku małżeńskiego, wypełnionego wewnętrzną walką. Jej efektem było opuszczenie męża (za jego zgodą) oraz niepełnoletnich jeszcze dwóch synów, a także Teodora (który ukończył 18 rok życia) i poświęceniem się wraz z córką na wyłączną służbę Bogu we wspólnocie ascetek. Miało to miejsce w roku 780 lub 781, wkrótce po śmierci cesarza ikonoklasty, Leona IV Chazara, będącego władcą w latach 775780. Odnośnie wspomnianego wyżej zagadnienia życia ascetycznego Teoktysty, które prowadziła w stolicy Cesarstwa Wschodniego, należy dodać, że nie zaniedbywała przy tym swoich obowiązków, jako matka, żona i gospodyni domowa. Trzeba przyznać, że w swoim dążeniu do zjednoczenia z Bogiem, starannie dobierała odpowiednie środki, prowadzące do osiągnięcia wyznaczonego przez siebie celu. Jednym z nich było czytanie Pisma Świętego i literatury ascetycznej. Ponadto wyrzekała się wielu przyjemności, kierując się m.in. powściągliwością w przyjmowaniu pokarmów. Zachęcała też swojego męża do powstrzymania się od pożycia małżeńskiego i skutecznie przekonała do tego na okres pięciu lat. Troszczyła się nie tylko o dobro duchowe Fotyna, lecz także otaczała macierzyńską miłością swoje dzieci. Jej aktywność na tym polu polegała głównie na wychowaniu córki i synów poprzez dawanie im uwag i przestróg oraz stosowanie metody rozsądnego karcenia. Cechowało ją również wyjątkowo życzliwe podejście do sług 
Historia Kościoła

i służących, których traktowała jak domowników, co wyróżniało ją w tej kwestii od innych zamożnych obywateli Konstantynopola. Trudno nie odnotować faktu, że tak, jak zabiegała o zaspokojenie podstawowych potrzeb egzystencjalnych, tak też troszczyła się o wyeliminowanie nadużyć związanych z naruszeniem szóstego i siódmego przykazania Bożego, u pracujących u niej dziewcząt oraz o nabycie potrzebnych dla nich cnót. Działalność Teoktysty nie ograniczała się tylko do zaspokojenia duchowych i materialnych potrzeb osób, znajdujących się w jej najbliższym otoczeniu. Posiadane przez nią środki, umożliwiały podjęcie aktywności dobroczynnej również wśród przychodzących do niej po jałmużnę ubogich mieszkańców stolicy i odległych stron. W ich zaś osobach gościła samego Chrystusa, który w ubogich zasiadał razem z nią do stołu i był jej współbiesiadnikiem. Ponadto jej dusza była przeniknięta miłością do życia ascetycznego, i to do tego stopnia, że stała się jego propagatorką, przekonując do tych praktyk swojego męża, dzieci oraz trzech braci Fotyna.

Nowy etap życia Teoktysty związany jest z decyzją, jaką podjęła po około 23 latach trwania ich związku małżeńskiego, wypełnionego wewnętrzną walką. Zakończyła się ona opuszczeniem męża oraz synów i poświęceniem się ascezie wraz z córką we wspólnocie bliskich sobie i podobnie myślących kobiet. Wiadomość ta stała się wydarzeniem, które wprowadziło w podziw mieszkańców stolicy. Zdumiało zwłaszcza jej krewne, zdziwiło znajomych i wprowadziło zamieszanie wśród świadków tak radykalnej decyzji. Wiele komentarzy wywołała także rezygnacja Fotyna i Teoktysty z światowych przyjemności. Nie bez echa pozostało zerwanie przez nich więzi rodzinnych, czy też wyrzeczenie się przez Fotyna prestiżowego zawodu. Godna uwagi jest zwłaszcza relacja Teodora, odnosząca się do pożegnalnego spotkania Teoktysty z zaproszonymi przez nią krewnymi. Warto podkreślić, że świadkowie tej uroczystości, patrząc na zdumiewający widok dobrowolnego oddalenia się Teoktysty od świata, byli pełni podziwu, nie szczędząc pochwał pod jej adresem. Jednakże już na początku tej drogi, pojawiły się trudności, spowodowane rozłąką z mężem i synami. Należy zaznaczyć, że po pokonaniu wielu przeszkód, otwierała się przed Teoktystą długo oczekiwana perspektywa, pozwalająca jej realizować ideały ascetyczne. Rzeczywistość okazała się do tego stopnia złożona, że zmuszona była odłożyć te plany z powodu osób zwalczających święte obrazy, którzy byli aktywni również po śmierci cesarza ikonoklasty, Leona IV Chazara. Teodor wspomina także o kolejnym dotkliwym utrudnieniu, uniemożliwiającym prowadzenie życia zakonnego przez Teoktystę. Miało ono miejsce za panowania cesarza Konstantyna VI 
(780-797). Główną zaś przyczyną prześladowań był jej sprzeciw wobec powtórnego, cudzołożnego związku tegoż władcy z jej krewną Teodotą (795 r.). Internowanie nie ominęło wówczas także Teoktysty oraz grupy nowicjuszek, prowadzących razem z nią życie ascetyczne. Teodor pisze, że pozbawiono je wolności na 30 dni. Teoktysta zaś była tam do tego stopnia źle traktowana przez kobiecą służbę więzienną, że stosowane wobec niej metody, zagrażały jej życiu. Zachęcała też cenobitów św. Teodora do mężnego znoszenia przeciwności, nie wyłączając męczeństwa oraz przestrzegając przed zdradą prawdy i opowiedzeniem się po stronie cudzołożnego monarchy.

Prześladowania ustały dopiero wtedy, gdy władzę objęła cesarzowa Irena (797-802), matka Konstantyna VI, która pozwoliła na powrót z wygnania wspólnotom zakonnym do ich macierzystych klasztorów. Nastały więc lata pokoju, umożliwiające Teoktyście realizować bez przeszkód pomoc wobec najbardziej potrzebujących. Jednocześnie nie chciała zbyt często widywać się z mnichami św. Teodora i innymi osobami, gdyż w jej przekonaniu pewna powściągliwość w tej materii, była istotnym elementem duchowości monastycznej. Dlatego rzadko opuszczała swój klasztor, a jeśli udawała się w podróż, to przede wszystkim w celu załatwienia niezbędnych spraw, związanych ze sprawowanym przez nią urzędem, jako przełożonej, przy czym i wówczas starała się zawsze zachowywać regułę zakonną.

Słowa kluczowe: bizantynologia, hagiografia, asceza, monastycyzm, cenobityzm. 